\title{
Pengaruh lama paparan dan masa kerja terhadap visus pada pekerja rental komputer di Kecamatan Sario dan Malalayang Kota Manado
}

\author{
${ }^{1}$ Mouren P. Lumolos \\ ${ }^{2}$ Hedison Polii \\ ${ }^{2}$ Sylvia R. Marunduh
}

\author{
${ }^{1}$ Kandidat Skripsi Fakultas Kedokteran Universitas Sam Ratulangi Manado \\ ${ }^{2}$ Bagian Fisiologi Fakultas Kedokteran Universitas Sam Ratulangi Manado \\ Email: oenyen9@gmail.com
}

\begin{abstract}
Eyes are important sense that need regular inspection and maintenance. Impaired vision caused by the use of computers, by The American Optometric Association called Computer Vision Syndrome (CVS). Among the many diseases of the eye, refractive errors is one of the eye disorders that very common throughout the world. Refractive disorders usually caused by the habit of reading too close, causing eyestrain (astenopia) and excessive light radiation received by the eye, among them the light radiation of computers and televisions. The objective of this study is to determine the effect of exposure time and working duration to visual aquity on computer rental workers in sario and malalayang regency. This study uses a consecutive sampling method with a sample of 67 respondents drawn from the working computer rentals in the city of Manado. To answer the problem formulation can be seen from the partial test in which the partial test aims to determine the effect of partially independent variable. Based on the results of the discussion can be said that the variables exposure time, and working duration significant effect on visual acuity Keywords: computer rental workers, frequency distribution and logistic regression
\end{abstract}

\begin{abstract}
Abstrak: Mata adalah panca indera penting yang perlu pemeriksaan dan perawatan secara teratur. Gangguan penglihatan yang disebabkan karena penggunaan komputer, oleh The American Optometric Association dinamakan Computer Vision Syndrome(CVS). Dari sekian banyaknya penyakit mata, ternyata kelainan refraksi pada mata merupakan salah satu kelainan mata yang sangat umum dijumpai di seluruh dunia. Kelainan refraksi biasa disebabkan oleh adanya faktor kebiasaan membaca terlalu dekat sehingga menyebabkan kelelahan pada mata (astenopia) dan radiasi cahaya yang berlebihan yang diterima mata, di antaranya adalah radiasi cahaya komputer dan televisi. Skripsi yang berjudul "Pengaruh Lama Paparan dan Masa Kerja Terhadap Visus Pada Pekerja Rental Komputer Di Kecamatan Sario Dan Malalayang Kota Manado" merupakan suatu penelitian tentang pengaruh lama paparan dan masa kerja terhadap visus pada pekerja rental komputer di Kecamatan Sario dan Malalayang kota Manado. Penelitian ini menggunakan metode Consecutive sampling dengan sampel sebanyak 67 responden yang diambil dari para pekerja rental komputer di Kota Manado. Untuk menjawab rumusan masalah dapat dilihat dari Uji parsial dimana Uji parsial bertujuan untuk mengetahui pengaruh secara parsial dari variabel independen. Bedasarkan hasil dari pembahasan bahwa dapat dikatakan variabel lama paparan, dan masa kerja memiliki pengaruh yang signifikan terhadap visus.
\end{abstract}

Kata kunci: pekerja rental komputer, distribusi frekuensi dan regresi logistik.

Mata adalah panca indera penting yang perlu pemeriksaan dan perawatan secara teratur. Pemeriksaan rutin pada mata sebaiknya dimulai pada usia dini. ${ }^{1}$ 
Di zaman modern ini dengan berkembang pesatnya dunia teknologi sehingga alat-alat elektronik seperti komputer, handphone menjadi alternativ bagi pengguna untuk memudahkan pekerjaan yang ada. Pada jenis pekerjaan tertentu ada kecenderungan akomodasi mata yang berlebih terutama pada pekerjaan yang membutuhkan penglihatan dengan jarak yang dekat sebagai contoh pada pekerja yang menggunakan komputer. ${ }^{2}$

Gangguan penglihatan yang disebabkan karena penggunaan komputer, oleh The American Optometric Association dinamakan Computer Vision Syndrome (CVS). Gejala CVS umumnya dikeluhkan setelah 3 jam penggunaan komputer secara terusmenerus atau setelah 6 jam penggunaan komputer tidak terus-menerus. Jika hal tersebut berlangsung lama maka akan menimbulkan gejala-gejala CVS yang dapat berlanjut pada gangguan penglihatan seperti kelainan refraksi.

Kelainan refraksi merupakan kelainan pembiasan sinar pada mata sehingga sinar tidak difokuskan pada retina atau bintik kuning, tetapi dapat di depan atau di belakang bintik kuning dan mungkin tidak terletak pada satu titik yang fokus. ${ }^{4}$ Kelainan refraksi biasa disebabkan oleh adanya faktor kebiasaan membaca terlalu dekat sehingga menyebabkan kelelahan pada mata (astenopia) dan radiasi cahaya yang berlebihan yang diterima mata, di antaranya adalah radiasi cahaya komputer dan televisi. Kelainan refraksi pada mata terdiri dari beberapa jenis seperti presbiopia, miopia, hiperopia, hipermetropi, dan astigmatisme. ${ }^{5}$

Hasil penelitian yang dilakukan terhadap pekerja yang menggunakan komputer di PT. Surveyor Indonesia menunjukan bahwa sebanyak $83,7 \%$ mengalami keluhan gangguan penglihatan Hasil penelitian lain juga menunjukkan sebanyak $78,6 \%$ pekerja yang menggunakan komputer di PT Bridgestone Tire Indonesia mengalami kelelahan mata. ${ }^{6}$ Dalam penelitian yang dilakukan pada operator komputer pelayanan pajak di Kantor Samsat Palembang menunjukkan bahwa $73,3 \%$ dari 30 responden merasakan keluhan pada mata setelah menggunakan komputer pada waktu yang cukup lama setiap harinya. Keluhan-keluhan yang dirasakan oleh responden akibat kelelahan mata sebagian besar terjadi pada saat bekerja sebanyak $60,8 \%$ dan setelah bekerja sebanyak 40,2\%. Hasil tersebut menunjukkan adanya pengaruh yang signifikan antara lama penggunaan komputer dan keluhan mata pada operator komputer. $^{7}$

Penelitian ini bertujuan untuk mengetahui bagaimana pengaruh lama paparan dan masa kerja terhadap visus pada pekerja rental komputer di Kecamatan Sario dan Malalayang kota Manado?

\section{METODE PENELITIAN}

Jenis penelitian ialah analitik dengan metode survei dan desain potong lintang. Penelitian dilakukan pada bulan September sampai Desember 2016 di rental komputer Kecamatan Sario dan Malalayang kota Manado. Populasi dalam penelitian ini sebanyak 67 orang dengan menggunakan rumus Lemeshow yang termasuk dalam kriteria penelitian yaitu sehat secara jasmani dan rohani pada saat dilakukan penelitian,bersedia menjadi responden Teknik pengambilan sampel dalam penelitian ini dilakukan secara non probability sampling dengan menggunakan metode Consecutive sampling. Variabel yang akan diteliti yaitu: visus, lama paparan, dan masa kerja. Data diperloleh melalui pengisian kuisioner dan pemeriksaan visus dengan menggunakan snellen card. Setalah jumlah sampel terpenuhi data diolah dengan menggunakan uji Regresi Logistik. diolah secara statistik menggunakan analisis Pearson bivariat.

Data diperoleh melalui pengisian kuisioner, pemeriksaan visus menggunakan snellen card. Data yang telah diperoleh diproses dengan software SPSS menggunakan uji Regresi Logistik.

\section{HASIL PENELITIAN}

Subjek pada penelitian ini adalah pekerja rental komputer di Kecamatan 
Sario dan Malalayang kota Manado sebanyak 67 Berdasarkan karakteristik usia, didapatkan paling banyak antara usia 21-30 sebesar $64,2 \%$. Hasil penelitian disajikan dalam Tabel 1.

Tabel 1. Karakteristik subjek berdasarkan usia

\begin{tabular}{ccc}
\hline Usia (Tahun) & $\mathbf{n}$ & $\mathbf{\%}$ \\
\hline$<20$ & 9 & 13,4 \\
$21-30$ & 43 & 64,2 \\
$31-40$ & 11 & 16,4 \\
$41-50$ & 4 & 6,0 \\
Total & 67 & 100 \\
\hline
\end{tabular}

Berdasarkan karakteristik jenis kelamin penelitian ini didominasi oleh lakilaki sebesar $65,7 \%$ sedangkan perempuan hanya sebesar $34,3 \%$. Hasil penelitian disajikan dalam Tabel 2

Tabel 2. Karakteristik subjek berdasarkan jenis kelamin

\begin{tabular}{ccc}
\hline Jenis Kelamin & n & \% \\
\hline Pria & 44 & 65,7 \\
Wanita & 23 & 34,3 \\
Total & 67 & 100 \\
\hline
\end{tabular}

Berdasarkan karakteristik menurut lama paparan 7-9 jam pada pekerja rental komputer sebesar $41,8 \%$ dan yang paling terkecil ialah lama paparan $>9$ jam sebesar 3\% (Tabel 3).

Tabel 3. Karakteristik subjek berdasarkan lama paparan

\begin{tabular}{ccc}
\hline $\begin{array}{c}\text { Lama Paparan } \\
(\text { Jam })\end{array}$ & n & \% \\
\hline $1-3$ & 10 & 14,9 \\
$4-6$ & 27 & 40,3 \\
$7-9$ & 28 & 41,8 \\
$>9$ & 2 & 3,0 \\
Total & 67 & 100 \\
\hline
\end{tabular}

Berdasarkan karakteristik subjek menurut masa kerja pada pekerja rental komputer didapatkan frekuensi terbanyak yang berkerja selama 1-3 tahun sebesar 47,8\% dan frekuesni terbanyak selanjutnya iatua selama 4-6 tahun sebesar 43,3\% dan $>6$ tahun sebesar 9\% (Tabel 4).
Tabel 4. Karalteristik subjek berdasarkan masa kerja

\begin{tabular}{ccc}
\hline $\begin{array}{c}\text { Masa Kerja } \\
\text { (Tahun) }\end{array}$ & n & \% \\
\hline $1-3$ & 32 & 47,8 \\
$4-6$ & 29 & 43,3 \\
$>6$ & 6 & 9,0 \\
Total & 67 & 100 \\
\hline
\end{tabular}

\section{Pengaruh Lama Paparan dan Masa} Kerja Terhadap Visus

1. Uji Goodness of Fit: bertujuan untuk melihat apakah model regresi logistik dapat digunakan untuk memrediksi nilai visus atau tidak. Goodness of fit lolos jika nilai signifikan hosmer dan lameshow datas 0,05 . Nilai signifikansi yang didapat yaitu 0,996 sehingga nilai ini datas 0,05 dan dapat disimpulkan bahwa model regresi logistic dapat digunakan untuk mengukur visus.

Tabel 5. Uji Goodness of Fit

\begin{tabular}{cccc}
\hline \multicolumn{4}{c}{ Hosmer and Lemeshow } \\
\hline Step & Chi-square & df & Sig. \\
1 & 0.884 & 7 & 0.996 \\
\hline
\end{tabular}

2. Uji F (Uji Simultan): bertujuan untuk mengetahui ada tidaknya pengaruh secara bersama-sama antar variabel.

Tabel 6. Omnibus Test of Model Coefficients

\begin{tabular}{ccccc}
\hline & & $\begin{array}{c}\text { Chi- } \\
\text { Square }\end{array}$ & df & Sig. \\
\hline \multirow{2}{*}{ STEP } & STEP & 31.229 & 7 & 0,000 \\
1 & BLOCK & 31.229 & 7 & 0,000 \\
& MODEL & 31.229 & 7 & 0,000 \\
\hline
\end{tabular}

3. Uji T ( Uji Parsial): bertujuan untuk mengetahui pengaruh secara parsial dari variabel yang yang diteliti. Apabila nilai signifikansi lebih kecil dari tingkat kesalahan (alpha) 0,05 maka dapat dikatakan bahwa ada pengaruh antar variabel. 
Tabel 7. Hasil Uji T (Uji Parsial)

\begin{tabular}{llcc}
\hline Variabel & df & Sig. \\
\hline Usia & 1 & 0.054 \\
Jenis Kelamin & 1 & 0.684 \\
Lama Paparan & 1 & 0.047 \\
Masa Kerja & 1 & 0.025 \\
& Tinggi Badan & 1 & 0.821 \\
& Berat Badan & 1 & 0.826 \\
& IMT & 1 & E 0.517 \\
Step $1^{\text {a }}$ & Constant & 1 & 0.012 \\
\hline
\end{tabular}

\section{Koefisien Determinasi}

Jika dilihat nilai Negelkerke R-Square yang besarnya 0,550 menunjukkan bahwa lama paparan, masa kerja mempengaruhi visus sebesar $55,0 \%$.

Tabel 8. Uji Adjusted R Square

\begin{tabular}{cccc}
\hline Step & $\begin{array}{c}\text {-2 Log } \\
\text { likelihood }\end{array}$ & $\begin{array}{c}\text { Cox \& } \\
\text { Snell R } \\
\text { Square }\end{array}$ & $\begin{array}{c}\text { Nagelkerke } \\
\text { R Square }\end{array}$ \\
\hline 1 & $44.668^{\mathrm{a}}$ & 0.373 & 0.55 \\
\hline
\end{tabular}

\section{BAHASAN}

Hampir setiap kegiatan manusia menggunakan mata, misalnya: menonton, menulis, berkendara dan lain-lain sehingga mata merupakan panca indera yang penting. Dengan berkembang pesatnya dunia teknologi, komputer menjadi salah satu alternatif bagi pengguna untuk memudahkan pekerjaan sehari-hari. Walaupun dapat mempermudah pekerjaan, apabila seseorang terlalu lama di depan komputer dapat menyebabkan beberapa keluhan. $^{8}$ Kumpulan keluhan yang disebabkan oleh penggunaan komputer disebut dengan Computer Vision Syndrome (CVS). Gejala CVS dibedakan menjadi keluhan gejala pada mata itu sendiri dan keluhan muskuloskeletal. Sekitar 75-90\% pengguna komputer mengeluhkan gejala oftalmikus. ${ }^{9}$

Dari hasil karakteristik subjek berdasarkan umur didapatkan sebanyak 64,2\% adalah usia 21-30 dan yang paling sedikit adalah usia 41-50 sebanyak 6\%. Dalam studi yang pernah dilakukan bahwa pengguna komputer yang berusia lebih dari
40 tahun cenderung mengeluhkan ketidaknyamanan saat berada didepan komputer. Hal tersebut dikarenakan sebagai suatu proses dari penuaan dimana terjadinya penurunan fungsi dalam penglihatan. Dengan adanya proses penuaan lensa akan mengurangi kemampuan otot siliaris untuk mengubah kurvatura lensa ketika akomodasi sehingga kemampuan akomodasi lensa akan berkurang yang akan dapat menimbulkan suatu keadan yang disebut dengan presbiopia. ${ }^{10}$ Hal ini sejalan dengan penelitian pada pekerja komputer di corporate customer care center dimana pekerja yang berusia $<45$ tahun sebagian besar 93,8\% mengalami keluhan CVS. ${ }^{11}$

Dari hasil karakteristik responden berdasarkan jenis kelamin didapatkan lakilaki sebesar $65,7 \%$ yang menunjukkan bahwa pekerja rental komputer di Kecamatan Sario dan Malalayang didominasi oleh laki-laki, sedangkan wanita hanya sebesar 34,3\%. Banyak penelitian menyebutkan bahwa perempuan lebih banyak untuk mengalami kejadian CVS daripada laki-laki itu dikarenakan oleh lapisan tear film perempuan cenderung lebih cepat menipis. Dalam penelitian sebelumnya di dapatkan nilai $p=0,003$ dengan odds ratio sebesar 5,231 yang menunjukkan bahwa jenis kelamin perempuan berhubungan secara signifikan dengan kejadian CVS. ${ }^{12}$ Tetapi ini tidak sejalan dengan penelitian pada pekerja rental komputer di Kecamatan Sario dan Malalayang karena penelitian di kecamatan tersebut didominasi oleh jenis kelamin lakilaki.

Pada variabel lama paparan didapatkan adanya pengaruhnya dengan visus. Lamanya penggunaan komputer tidak lebih dari 4 jam seharin apabila sudah melebihi dari itu, mata dipaksakan untuk terlalu lama memfokuksan pada layar komputer yang menyebabkan otot-otot maata menjadi tegang sehingga terjadi penurunan frekuensi berkedip dan produksi air mata menurun yang dapat menyebabkan gejala CVS. Dari karakteristik menurut lama 
paparan paling banyak yaitu 7-9 jam dan sudah melebihi dari 4 jam. ${ }^{13,14}$

CVS lebih tinggi pada pengguna Visual display terminal (VDT )yang bekerja dengan komputer kurang dari lima tahun. Dimana dalam penelitian ini didaptatkan pekerja rental dengan masa kerja 1-3 tahun sebanyak $47,8 \%$ dan menunjukkan adanya pengaruh masa kerja terhadap visus Penelitian lain juga melaporkan bahwa kejadian CVS lebih banyak pada pekerja pengguna komputer yang telah bekerja selama lebih dari 10 tahun, peningkatan jam kerja di depan komputer tanpa diselingi oleh istirahat dapat menurunkan kemampuan akomodasi sehingga akan memperberat gejala CVS pada pekerja rental komputer. ${ }^{1}$

\section{SIMPULAN}

Dari hasil penelitian yang ada dapat disimpulkan bahwa lama paparan dan masa kerja dapat mempengaruhi visus dengan nilai signifikan lebih kecil dari tinkgkat kesalahan yaitu 0,05

\section{SARAN}

1. Bagi pekerja rental computer agar supaya dapat melakukan istirahat setelah 2 jam terpapar oleh komputer.

2. Bagi peneliti selanjutnya, disarankan untuk membuat suatu penelitian tentang pengaruh lama pengunaan dan intensitas penerangan smarthphone terhadap visus pada remaja.

3. Disarankan juga untuk meneliti tentang hubungan masa kerja terhadap terjadinya penurunan visus pada pekerja tukang las. telinga dan gangguan pendengaran yang berat.

\section{DAFTAR PUSTAKA}

1. Naser A, Zaiter A. An Expert System For Diagnosing Eye Disease Using Clips, Journal of Theoretical and Applied Information Technology;2008.

2. Faiz N. Keluhan mata berkomputer. Upaya pengendalian kecelakaan kerja. 2007; 6:220-30.

3. American Optometric Association (AOA). 2006. Komputer vision syndrome (CVS).
4. Ilyas S. Ilmu penyakit mata. (5th ed). Jakarta: Sagung Seto, 2014.

5. Fachrian D. Penglihatan dan sindrom komputer. Majalah kedokteran. 2008;59(6).

6. Setiawan I. Analisis Hubungan Faktor Karateristik Pekerja, Durasi Kerja Alat Kerja dan Tingkat Pencahayaan dengan Keluhan Subjektif Kelelahan Mata pada Pengguna Komputer di PT. Surveyor Indonesia Tahun 2012.

7. Hana, Lilian. Tinjauan Tingkat Pencahayaan dan Keadaan Visual Display Terkait Keluhan Subyektif Kelelahan Mata Pada Pekerja Yang Menggunakan Komputer Di Ruangan Kantor PT. Bridgestone Tire Indonesia Bekasi Plant Bulan Desember Tahun 2008. Depok: Universitas Indonesia, 2008.

8. Mashud, 2008. Komputer, Ergonomi dan Kesehatan Kerja. [cited 28 Oktober 2016]. Available from: http://arsipegianto.tripod.com/komput er_dan_kesehatan_kerja.pdf

9. Anshel, J. Visual Ergonomics in the Workplace. AAOHN.J. 2007;55:41420.

10. Fauziah I. Upaya Untuk Mengurangi Kelelahan Mata pada Tenaga Kerja yang Menggunakan Komputer di Rumah Sakit "X" Jakarta. Program Pascasarjana UI; 2003.

11. Nourmayantu N. Faktor-faktor yang berhubungan dengan keluhan kelelahan mata pada pekerja pengguna computer di Corporate Customer Care center (C4) PT. Telekomunikasi Indonesia. Jakarta: UIN Syarif Hidayatulah; 2009.

12. Azkadina A. Hubungan antara factor risiko individual dan computer terhadap kejadian Computer Vision Syndrome (CVS). Semarang: Universitas Diponegoro; 2012.

13. Rosenfield M. Computer vision syndrome: a review of ocular causes and potential treatments. Ophthalmic Physiol Opt. 2011;31(5):502-15.

14. Rachmawaru N. Hubungan Intensitas penerngan dan lama paparan cahaya layar monitor dengan kelelahan mata pekerja komputer di kelurahan X. Surakarta: Universitas Sebelas Maret; 2011. 